\title{
Extruded feed in different volume-concentrate ratios: in-vitro fermentation kinetics, consumption, and evaluation of lambs' metabolic profile
}

Received: Jan, 2019; Accepted: Jul, 2020

\author{
Karla Alves Oliveira ${ }^{1 *}$, Jhone Tallison Lira de Sousa ${ }^{2}$, Luciano Fernandes \\ Sousa $^{3}$, Adriana Lima Silva ${ }^{4}$, Laura Ferrari Monteiro Varanis ${ }^{4}$, Gilberto de \\ Lima Macedo Júnior ${ }^{4}$
}

\begin{abstract}
This study aimed both to evaluate the metabolic profile of lambs fed with extruded forage and concentrate containing different roughageconcentrate ratios (R:C) and to evaluate in-vitro ruminal fermentation kinetics of these rations. An experiment was carried out with 20 weanling, female crossbred lambs ( $1 / 2$ Dorper x $1 / 2$ Santa Inês) aged $120 \pm 8$ days. The treatments were four R:C ratios of extruded forage (Foragge $\mathbb{R})$ and extruded

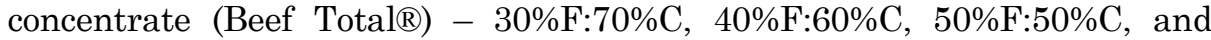
$60 \% \mathrm{~F}: 40 \% \mathrm{C}$ - distributed randomly with five replicates. The analysis targeted energy metabolites (VLDL, triglycerides, and cholesterol), hepatic metabolites (alkaline phosphatase, gamma glutamyltransferase [GGT], and aspartate aminotransferase [AST]), and protein metabolites (total protein, uric acid, urea, creatinine, albumin, and globulin). In-vitro gas production was quantified by inoculating the extruded rations in bovine ruminal fluid with the following forage:concentrate proportions evaluated: $30 \% \mathrm{~F}: 70 \% \mathrm{C}$, 40\%F:60\%C, 50\%F:50\%C, 60\%F:40\%C and 70\%F:30\%C. Fermentation kinetic values were compared using parallelism test and curve identity at the error probability level of 5\%. A regression study was used to compare the means of the metabolites at the error probability level of 5\%. Average dry matter intake data are provided descriptively. The extruded ration increased the hepatic metabolites (GGT and AST) without compromising the liver and kept the energy metabolites stable. Similarly, the serum concentration of protein metabolites remained at normal levels recommended to the ovine species. In-vitro fermentation pattern displayed high gas production associated with high ration digestibility. The extruded ration provides protein and energy supply to meet the animals' nutritional requirements without compromising their health.
\end{abstract}

Keywords: Energy, Ovis aries, Protein, Ruminant.

\footnotetext{
1 Unesp Jaboticabal, São Paulo

${ }^{2}$ Federal University of Tocantins

${ }^{3}$ Zootechnics undergraduate course, Federal University of Tocantins, Campus Araguaína, TO.

${ }^{4}$ School of Veterinary Medicine, Federal University of Uberlândia

* Corresponding author: Av. Rui Barbosa, s/n, Colina-SP, CEP: 14770-000. e-mail: karla.alves.oliveira@hotmail.com
} 


\section{Introduction}

Extrusion is a processing way whereby food is submitted to physical, chemical and thermal treatment. High pressure, high temperature and controlled humidity for a short time expand the ingredients mixture and increase the exposure of nutrients contained in the plant cell (LIMA JUNIOR et al., 2011). In current production systems, where the production flow has become increasingly continuous, practices are necessary that facilitate daily management and optimize animal performance. Depending on the food in question and on the processing type, extrusion leads to increased availability of protein and some essential amino acids that reach the small intestine; it also increases dry matter intake and feed efficiency (GIALLONGO et al., 2015).

The quantity and effectiveness of fiber are parameters that directly affect the intake pattern, rumen fermentation, and consequently food digestibility (KOZLOSKI et al., 2006). As a result, it directly impacts the productive indexes in a production system. Little is known about the effects of food on ruminal fermentation kinetics, especially when it comes to extruded food for ruminants.

Extruded food is expected to interfere with gas production responses and ruminal fermentation kinetics, since different fiber fractions are determining factors for ruminal fermentation patterns and dry matter degradability. Thus, it is necessary to assess the impacts of using this type of food on the animal's physiological conditions by determining the degree of change brought about by the use of extruded food.

The evaluation of an animal's energy metabolism can support the understanding of the origins of heat production or energy expenditure, allowing inferences about several aspects of zootechnical interest, such as feed conversion and efficiency. For a complete assessment of an animal's nutritional status, it is also necessary to assess its metabolic profile, 
including protein metabolism, which has a great impact on the body of knowledge of how animals respond to a certain type of food. Moreover, the metabolic profile serves as an auxiliary tool in the clinical diagnosis of metabolic diseases and in the implementation of nutritional changes to prevent such disorders (PEIXOTO; OSÓRIO, 2007).

This study aims to evaluate the metabolic profile of freshly weaned lambs fed with extruded rations with different proportions of roughage:concentrate (R:C) and to evaluate the kinetics of in-vitro ruminal fermentation for these diets.

\section{Material and methods}

The experiments were carried out in the Goats and Sheep sector of the Capim Branco Experimental Farm at Federal University of Uberlândia (UFU), located in the city of Uberlândia, State of Minas Gerais, Brazil. The experimental protocol was approved by the Ethics Committee on the Use of Animals (Approval No. 92/2016). The first experiment, conducted with animals, lasted 90 days from March to June, 2016. It targeted 20 crossbred $1 / 2$ Dorper x $1 \frac{1}{2}$ Santa Inês lambs aged approximately $120 \pm 8$ days old with an average of $25 \pm 2.8 \mathrm{~kg}$ of live weight. They were distributed in four slatted wooden floor stalls where they could drink water and mineral salt at will.

All animals were dewormed before the experiment using Monepantelbased anthelmintic. The total ration was made of two types of pellets: the

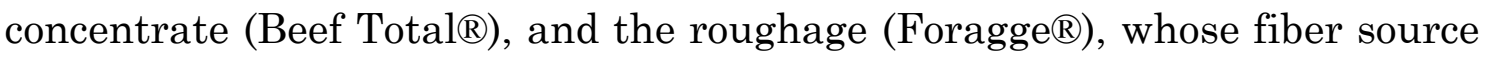
was the aerial part of the sugar cane (plant). The feed was mixed by the manufacturer in a single product. However, due to the heterogeneous composition of the total ration at the time of supply to the animals, a new homogenization was performed to reduce both selection by the animals and discrepancies in the feed. The ration was provided twice a day at $08 \mathrm{AM}$ and 4 PM. Dry matter intake (DMI) was measured as the difference between the 
amount of food provided and the leftovers of the following day. The treatments consisted of four ratios of roughage and concentrate (R:C) of the

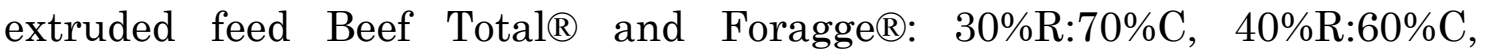
50\%R:50\%C, and 60\%R:40\%C. Table 1 shows the chemical composition of the feed and the $\mathrm{R}: \mathrm{C}$ ratio.

Table 1. Chemical composition of extruded roughage (Foragge $\left.{ }^{\circledR}\right)$ and concentrate (Beef Total $\left.{ }^{\circledR}\right)$ and treatments distribution

\begin{tabular}{|c|c|c|}
\hline \multirow{2}{*}{ Nutrients } & \multicolumn{2}{|c|}{ Chemical Composition } \\
\hline & Beef Total $^{\circledR}(\%$ DM) & Foragge $^{\circledast}(\% \mathrm{DM})$ \\
\hline Crude Protein & 18.77 & 9.81 \\
\hline Neutral Detergent Fiber & 12.95 & 32.27 \\
\hline Acid Detergent Fiber & 8.61 & 20.98 \\
\hline Ether Extract & 1.39 & 1.50 \\
\hline Mineral Matter & 5.73 & 6.55 \\
\hline Dry Matter (\% NM) & 92.48 & 96.62 \\
\hline \multirow{2}{*}{ Treatments } & \multicolumn{2}{|c|}{ Treatment Distribution } \\
\hline & Foragge $^{\circledR}$ (\% on diet) & Beef Total ${ }^{\circledast}$ (\% on diet) \\
\hline 30R:70C & 30 & 70 \\
\hline 40R:60C & 40 & 60 \\
\hline 50R:50C & 50 & 50 \\
\hline 60R:40C & 60 & 40 \\
\hline $70 \mathrm{R}: 30 \mathrm{C}^{1}$ & 70 & 30 \\
\hline
\end{tabular}

*Treatment included only in the laboratory experiment (fermentation kinetics). DM: dry matter; NM: natural matter.

To assess protein, energy and liver metabolites, blood samples were collected every 21 days (days $0,21,42,63$, and 84) right before the first daily feeding, through puncture of the jugular vein with the aid of a Vacutainer $^{\circledR}$ needle adapter coupled to an anticoagulant-free tube. Right after blood collection, the samples were centrifuged at a speed of $3000 \mathrm{rpm}$ in a centrifuge with capacity for 12 tubes. Then, the blood samples were pipetted in Eppendorfs ${ }^{\circledR}$ tubes, frozen and taken to the laboratory to be processed in an automatic biochemical analyzer using spectrophotometric techniques and a commercial kit from Labtest ${ }^{\mathbb{Q}}$. 
The analysis of energy metabolites targeted triglycerides, cholesterol, and very low-density lipoprotein (VLDL), which was calculated using the formula proposed by Friedewald et al. (1972), dividing the amount of triglycerides by five. The targeted hepatic metabolites were alkaline phosphatase, gamma glutamyltransferase (GGT), and aspartate aminotransferase (AST). The protein metabolites were total proteins, uric acid, urea, creatinine, albumin, and globulin.

To evaluate in-vitro fermentation kinetics, the diets (the measurement of gas production was performed in five proportions of R:C: 30\%R:70\%C，70\%R:30\%C，40\%R:60\%C，50\%R:50\%C，and 60\%R:40\%C) were submitted to a laboratory test for gas production and degradability. To this end, an adaptation of the "Hohenheim Gas Test" technique developed by Menke et al. (1979) used graduated 100-ml glass syringes to measure gas production. In total, $0.2 \mathrm{~g}$ of the tested diets (Foragge and Beef Total) were used, and the syringes were incubated with $10 \mathrm{ml}$ of inoculum and $20 \mathrm{ml}$ of culture medium. The inoculants were collected from five cattle fed with pasture and concentrated supplement. The times used to measure the volume of gases produced were: $3,6,9,12,24,48,72$, and 96 hours after inoculation. The data obtained were run using blanks (sample-free syringes). After such a procedure, the model proposed by France et al. (1993) was adjusted to the data. In the laboratory, dry matter digestibility of extruded feed was also estimated. For the laboratory experiment, the fermentation kinetics values were compared using the parallelism and curve identity test according to Regazzi and Silva (2004), at the error probability level of 5\% ( $p<0.05)$.

The experimental design with the animals was completely randomized, with repeated measures over time, four treatments and five repetitions per treatment. The average dry matter intake data are presented descriptively. To compare the averages of the metabolites, a regression study was carried out at a error probability level of $5 \%$. 


\section{Results and discussion}

Graphic 1 shows the animal's dry matter intake (DMI) in each stall (mean stall). In all treatments, DMI increased until the $10^{\text {th }}$ week, a fact explained by their physiological growth stage. The sheep have a sigmoid growth curve: during the initial phase (after birth) they show slow growth, which accelerates until puberty and later gradually reduces before stopping when the animal reaches maturity (SILVA, 2017). Therefore, the increase in DMI can be explained by the fact that the animals are constantly growing during the experiment, since they reached puberty at the end of the experiment, when DMI did reduce.

Graphic 1. Dry matter intake (DMI) for different R:C ratios in the experiment.

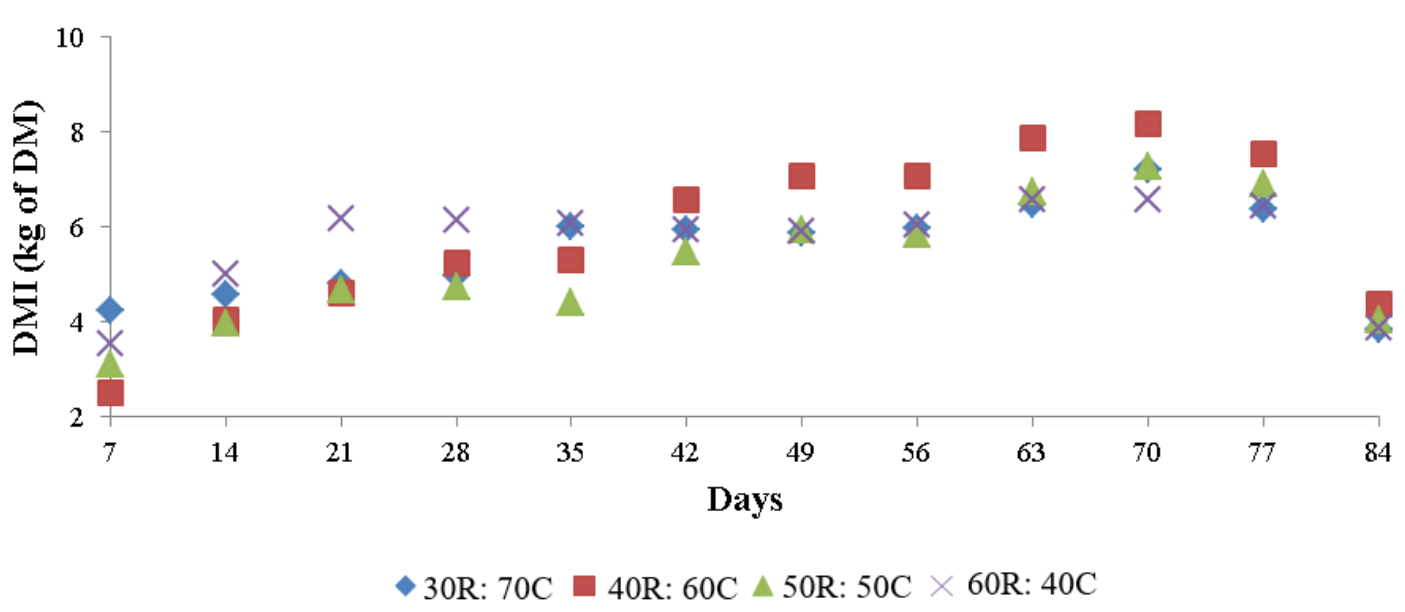

At the beginning of the experiment, the animals supplied with the 60R:40C ratio showed greater dry matter intake. However, after the $6^{\text {th }}$ week (day 42) the animals provided with the 40R:60C ratio showed higher dry matter intake.

The 40R:60C ratio showed greater in-vitro digestibility (Table 3), which suggest a potentially greater exposure to and consequent use of feed nutrients within the rumen environment under this condition. This directly 
affects the passage rate, resulting in greater intake by the animals. However, one should note that the intake data (mean of the stall) are descriptive because there was no repetition of stalls.

Table 2 shows the total gas production $\left(\mathrm{CH}_{4}\right.$ and $\left.\mathrm{CO}_{2}\right)$ of the extruded feed Beef Total ${ }^{\circledR}$ in the different sample incubation times. According to the identity and parallelism test, there was greater gas production in the diet containing $30 \%$ roughage and $70 \%$ concentrate. This occurred because of the greater availability of readily fermentable carbohydrates (non-fibrous carbohydrates) considering the greater amount of concentrate contained in the feed $(70 \%)$. However, the diet with 70\% roughage and 30\% concentrate resulted in the lowest gas production because of the greater amount of roughage in the extruded feed (i.e., fiber significantly changes the fermentation pattern). Ellis et al. (2008) state that diets with a higher proportion of roughage result in greater production of $\mathrm{CH}_{4}$ and $\mathrm{CO}_{2}$ in the rumen. However, when it comes to the speed of gas production, it is higher in diets with a high proportion of concentrate, since it is highly fermentable in the rumen and rapidly degraded.

Table 2. Gas production (mL) of extruded ration with different $\mathrm{R}: \mathrm{C}$ ratios as a function of incubation time $(\mathrm{h})$, and result of the Parallelism and Identity test of curves

\begin{tabular}{cccccc}
\hline Sample & $30 \mathrm{R}: 70 \mathrm{C}$ & $40 \mathrm{R}: 60 \mathrm{C}$ & $50 \mathrm{R}: 50 \mathrm{C}$ & $60 \mathrm{R}: 40 \mathrm{C}$ & $70 \mathrm{R}: 30 \mathrm{C}$ \\
\hline 0 & 0 & 0 & 0 & 0 & 0 \\
3 & 30.312 & 24.562 & 25.216 & 22.672 & 18.471 \\
6 & 69.215 & 64.349 & 65.431 & 60.415 & 51.545 \\
9 & 103.61 & 100.62 & 101.86 & 95.328 & 82.193 \\
12 & 132.68 & 131.35 & 132.54 & 125.26 & 108.95 \\
24 & 205.89 & 206.42 & 206.61 & 200.27 & 180.35 \\
48 & 250.79 & 247.31 & 245.86 & 243.46 & 229.29 \\
72 & 258.42 & 252.81 & 250.91 & 249.8 & 238.97 \\
96 & 259.66 & 253.5 & 251.52 & 250.67 & 240.79 \\
\hline Parallelism & $\mathrm{a}$ & $\mathrm{b}$ & $\mathrm{b}$ & $\mathrm{b}$ & $\mathrm{c}$ \\
Identity & $\mathrm{A}$ & $\mathrm{B}$ & $\mathrm{B}$ & $\mathrm{B}$ & $\mathrm{C}$ \\
\hline
\end{tabular}

Values arranged in a column, accompanied by equal lowercase letters on the same line, are paralleled according the curve parallelism test at $5 \%$ probability. Values arranged in a column, accompanied by equal capital letters on the same line, are identical according to the $5 \%$ curve identity test. 
The gas production data for the 50R:50C, 40R:60C and 60R:40C treatments were the same and had identical curves according to the parallelism and identity test. Graphic 2 shows the fermentation kinetics, with the values of gas production as a function of the incubation time. As mentioned previously, the ration with highest percentage of concentrate showed the greatest amount, in volume, of gas production. In the present experiment, due to the extrusion process, all feeds presented high volumes of gas production, close to the values found for the corn grain (REGADAS FILHO et al., 2011).

Sousa et al. (2014) evaluated the in-vitro fermentation kinetics and gas production for diets with babassu mesocarp flour. When they compared the gas production for the feeds with babassu flour and those with corn grain, they found a higher total gas production for the diets with corn grain (284.46mL). They ascribed this result to the lower content of neutral detergent fiber (NDF) and lignin contained in corn when compared to babassu mesocarp flour. Similarly to this experiment, the NDF of roughage becomes more digestible with the extrusion process, increasing the availability and accessibility of carbohydrates to ruminal microorganisms and thus changing the fermentation pattern.

Graphic 2. Total gas production of extruded ration in different R: C ratios as a function of invitro incubation time.

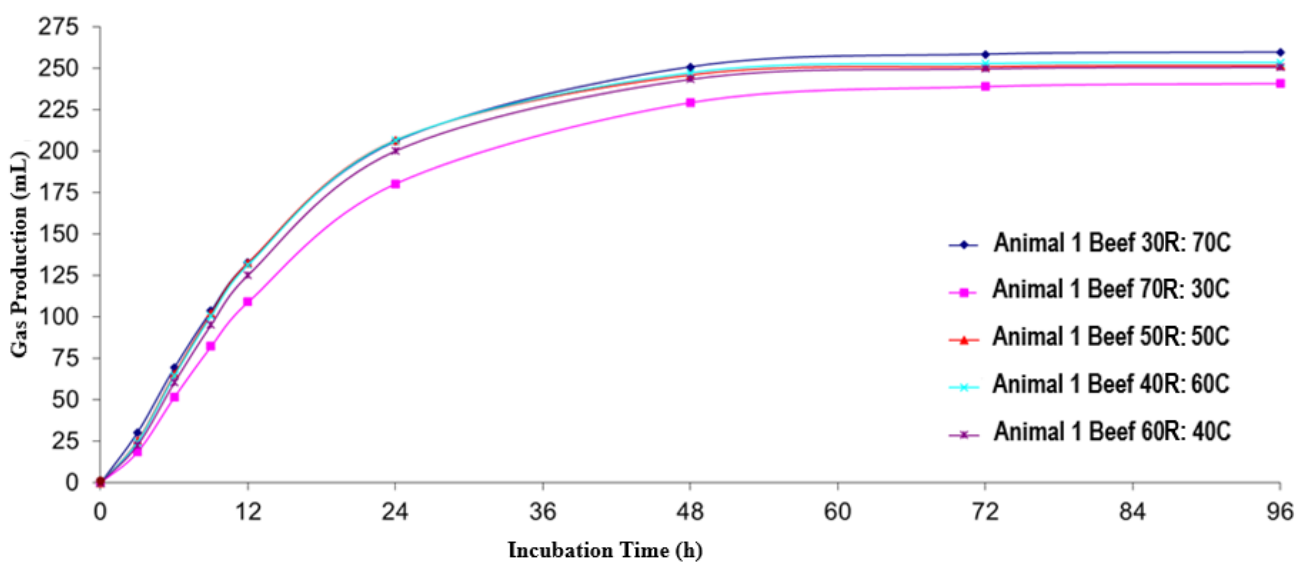


The dry matter digestibility was higher in the 40R:60C diet, with a value of $82.37 \%$ (Table 3). This value is related to the adequate supply of energy and nitrogen sources to microorganisms, in order to allow synergism in the use of these compounds.

Table 3. Dry matter digestibility and in-vitro colonization time of extruded ration with different R: C

\begin{tabular}{cccccc}
\multicolumn{6}{c}{ ratios } \\
\hline Parameter & 30R:70C & $40 \mathrm{R}: 60 \mathrm{C}$ & $50 \mathrm{R}: 50 \mathrm{C}$ & 60R:40C & 70R:30C \\
\hline DMD (\%) & 80.22 & 82.37 & 79.29 & 80.80 & 78.19 \\
Lag (h) & 0.327 & 0.625 & 0.586 & 0.416 & 1.128 \\
\hline
\end{tabular}

DMD: dry matter digestibility; Lag: incubation time.

The lowest digestibility value was $78.20 \%$ for the $70 \mathrm{R}: 30 \mathrm{C}$ ration (Table 3). Such dry matter digestibility results are considered high when compared to non-extruded food. This fact is a consequence of the extrusion process, as already mentioned: extrusion causes greater exposure to plant cell nutrients and consequently increases food digestibility. As expected, the colonization time was longer for the proportion with fewer digestibilities (70R:30C). This fact is explained by the greater amount of roughage (70\%), which is the fibrous fraction with the most difficult colonization by microorganisms, when compared to non-fibrous foods (concentrate).

Due to the results described above, there was a difference for the blood concentration of alkaline phosphatase only for the evaluation period, with a linear increase in the metabolite from the beginning to the end of the experiment (Table 4). Factors such as age development, race and sex can influence the blood concentration of this enzyme (MEIRA JUNIOR et al., 2009). Thus, the concentration of alkaline phosphatase, which is $69 \%$ above the reference value, can be explained by the increase in DMI and also in body mass and metabolic activity, since the animals were growing, indicating no lesions or changes in the liver. 
Table 4. Effect of different R:C ratios of extruded ration on serum concentrations of alkaline phosphatase (U / L), VLDL (mg / dL), and triglycerides (mg / dL)

\begin{tabular}{cccc}
\hline R:C (\%) & Alkaline Phosphatase & VLDL & Triglycerides \\
\hline 30R:70C & 674.31 & 6.00 & 30.00 \\
40R:60C & 634.53 & 4.82 & 24.12 \\
50R:50C & 701.47 & 6.37 & 31.85 \\
60R:40C & 605.63 & 5.60 & 28.04 \\
\hline Period & Alkaline Phosphatase $^{1}$ & VLDL & Triglycerides \\
\hline 0 & 585.81 & 9.95 & 49.77 \\
21 & 464.31 & 4.18 & 20.90 \\
42 & 646.15 & 5.29 & 26.45 \\
63 & 790.17 & 3.17 & 15.88 \\
84 & 860.00 & 5.09 & 25.47 \\
\hline P & 0.0042 & 0.4142 & 0.4143 \\
\hline Mean & 653.86 & 5.68 & 28.43 \\
& & & 30.00 \\
CV (\%) & 30.83 & 31.04 & $9.0-30.0$ \\
RV* & $68.0-387.0$ & $3.0-4.0$ & \\
\hline
\end{tabular}

VLDL: very low density lipoprotein; CV: Coefficient of Variation; RV: Reference values according to Kanekoet al. (2008). ${ }^{1} \mathrm{Y}=494.448182+4.162962 \mathrm{X}, \mathrm{R}^{2}=76.05 \%$.

The levels of VLDL and triglycerides also showed no statistically significant differences in terms of treatment and period. VLDL levels were $42 \%$ above the reference value, according to Kaneko et al. (2008). Such change should not be interpreted as the only parameter of change in the body's lipid levels, since the average triglyceride values remained within the limit range, and variations in the triglyceride concentrations are associated with the hydrolysis of this substrate for the release of free fatty acids in cases of energy shortage in the tissues. These statements indicate that the rations provided enough energy to maintain the animals' energy stability, as shown in Table 3.

There was interaction between treatment and period for the values of GGT, AST and cholesterol (Table 5). The average concentration of GGT is $67 \%$ above the reference value, which can be ascribed to the lambs' high 
metabolic activity. Thus, the interaction between period and treatment indicates an increase in the values of these metabolites as responses to the growth and normal development of these animals. Nunes et al. (2010) and Varanis (2018) still assume that Santa Inês sheep naturally have higher serum concentrations of this enzyme.

Although the AST enzyme remained within the normal values for the species, the GGT and alkaline phosphatase were found to be $67 \%$ and $69 \%$, respectively, above the recommended value, which would indicate liver damage. However, intrinsic factors such as the growth-related high metabolic rate and the higher DMI may have been the cause of the variations in the values of these enzymes. Gas production in the rumen is directly related to the production of volatile fatty acids (VFAs) - when producing VFAs in the rumen, heat is released in the form of metabolic heat through the body surface, and carbon dioxide $\left(\mathrm{CO}_{2}\right)$ and methane $\left(\mathrm{CH}_{4}\right)$ are produced (DUKES and SWENSON, 1977; MOREIRA et al., 2009). Therefore, it is possible to relate the high gas production found in this study (Graphic 2) to a high production of VFAs, and knowing that these VFAs are metabolized in the liver (especially the propionic acid), they can increase the hepatic activity of these animals, also explaining the high concentrations of alkaline phosphatase and GGT found.

Table 5. Effect of treatments, periods and its interactions on serum concentrations of gama glutamyltransferase (GGT, U / L), aspartate aminotransferase (AST, U / L), and cholesterol (mg / dL)

\begin{tabular}{|c|c|c|c|c|}
\hline \multirow{2}{*}{ Period } & \multicolumn{4}{|c|}{ GGT } \\
\hline & 30R:70C & 40R:60C & 50R:50C & 60R:40C \\
\hline 0 & 81.42 & 72.20 & 82.00 & 59.40 \\
\hline 21 & 79.85 & 110.60 & 85.20 & 82.00 \\
\hline 42 & 84.50 & 76.80 & 91.75 & 77.40 \\
\hline 63 & 82.40 & 98.60 & 102.66 & 107.50 \\
\hline 84 & 105.20 & 80.40 & 84.75 & 117.25 \\
\hline $\mathrm{P}$ & 0.2325 & 0.4145 & 0.6987 & 0.0056 \\
\hline Mean & \multicolumn{4}{|c|}{86.78} \\
\hline $\mathrm{CV}$ & \multicolumn{4}{|c|}{23.68} \\
\hline
\end{tabular}




\begin{tabular}{|c|c|c|c|c|}
\hline $\mathrm{RV}$ & \multicolumn{4}{|c|}{$20-52$} \\
\hline \multirow{2}{*}{ Period } & \multicolumn{4}{|c|}{ AST } \\
\hline & 30R:70C & 40R:60C & 50R:50C & 60R:40C ${ }^{2}$ \\
\hline 0 & 80.42 & 80.2 & 80 & 60.2 \\
\hline 21 & 67.42 & 71.8 & 69.2 & 93.6 \\
\hline 42 & 78.83 & 71.6 & 61.25 & 85.6 \\
\hline 63 & 78.4 & 66 & 74.33 & 84.25 \\
\hline 84 & 70.25 & 77 & 91.5 & 97.75 \\
\hline $\mathrm{P}$ & 0.5896 & 0.6987 & 0.3748 & 0.0125 \\
\hline Mean & \multicolumn{4}{|c|}{76.72} \\
\hline $\mathrm{CV}$ & \multicolumn{4}{|c|}{21.08} \\
\hline $\mathrm{RV}$ & \multicolumn{4}{|c|}{$60-280$} \\
\hline \multirow{2}{*}{ Period } & \multicolumn{4}{|c|}{ Cholesterol } \\
\hline & 30R:70C ${ }^{3}$ & 40R:60C & 50R:50C & 60R:40C \\
\hline 0 & 53.42 & 40.00 & 40.20 & 66.60 \\
\hline 21 & 45.00 & 39.20 & 42.80 & 44.40 \\
\hline 42 & 20.33 & 45.00 & 28.50 & 32.00 \\
\hline 63 & 31.60 & 37.00 & 35.66 & 26.00 \\
\hline 84 & 28.75 & 30.60 & 46.25 & 39.00 \\
\hline $\mathrm{P}$ & 0.04215 & 0.3696 & 0.3789 & 0.0012 \\
\hline Mean & \multicolumn{4}{|c|}{39.17} \\
\hline $\mathrm{CV}$ & \multicolumn{4}{|c|}{37.02} \\
\hline $\mathrm{RV}$ & \multicolumn{4}{|c|}{$56-72$} \\
\hline
\end{tabular}

CV: Coefficient of Variation; RV: Reference values according to Kaneko et al. (2008). ${ }^{1} \mathrm{Y}=60.47000+$ $0.672381 \mathrm{X}, \mathrm{R}^{2}=90.64 \% ;{ }^{2} \mathrm{Y}=71.13000+0.313095 \mathrm{X}, \mathrm{R}^{2}=50.89 \% ;{ }^{3} \mathrm{Y}=55.101020-0.939530 \mathrm{X}-$ $0.007627 \mathrm{X}^{2}, \mathrm{R}^{2}=78.67 \% ;{ }^{4} \mathrm{Y}=67.291429-1.395374 \mathrm{X}+0.012439 \mathrm{X}^{2}, \mathrm{R}^{2}=98.76 \%$.

The average cholesterol levels were $40 \%$ below the recommended reference value, due to the lower content of ether extract in the extruded feed. The ether extract contained in the food provides fatty acids to be absorbed and converted to rumen acetate, which is the precursor fatty acid for cholesterol synthesis. For a better evaluation of energy metabolism, triglycerides and lipoproteins, which were normal in this experiment, should also be taken into account, indicating that the energy levels of the animals did not suffer great variations. The protein metabolism profile (Table 6) 
remained at normal levels, and since blood proteins are synthesized mainly by the liver, the results pointed to no evidence of liver damage. 
Table 6. Average values of protein metabolites of lambs receiving extruded ration with different R:C

\begin{tabular}{|c|c|c|c|c|c|c|}
\hline \multirow[b]{2}{*}{$\% \mathrm{R}: \mathrm{C}$} & \multicolumn{6}{|c|}{ Protein metabolites } \\
\hline & $\begin{array}{l}\text { Total Protein } \\
(\mathrm{mg} / \mathrm{dL})\end{array}$ & $\begin{array}{l}\text { Uric Acid } \\
(\mathrm{mg} / \mathrm{dL})\end{array}$ & $\begin{array}{c}\text { Urea } \\
(\mathrm{mg} / \mathrm{dL})\end{array}$ & $\begin{array}{c}\text { Creatinine } \\
(\mathrm{mg} / \mathrm{dL})\end{array}$ & $\begin{array}{l}\text { Albumin } \\
\text { (g/dL) }\end{array}$ & $\begin{array}{c}\text { Globulin }(\mathrm{mg} / \\
\mathrm{dL})\end{array}$ \\
\hline 30R:70C & 5.76 & 0.17 & 19.82 & 1.22 & 2.27 & 3.49 \\
\hline 40R:60C & 6.48 & 0.13 & 18.92 & 1.29 & 2.31 & 4.16 \\
\hline 50R:50C & 5.57 & 0.11 & 17.00 & 1.29 & 2.46 & 3.10 \\
\hline 60R:40C & 6.30 & 0.13 & 18.33 & 1.25 & 2.45 & 3.85 \\
\hline $\mathrm{P}$ & 0.2589 & 0.8974 & 0.1489 & 0.3366 & 0.3896 & 0.5569 \\
\hline Period & Total Protein ${ }^{1}$ & Uric Acid $^{2}$ & Urea $^{3}$ & Creatinine $^{4}$ & Albumin & Globulin $^{5}$ \\
\hline 0 & 5.87 & 0.19 & 21.94 & 1.45 & 2.27 & 3.59 \\
\hline 21 & 5.03 & 0.15 & 17.35 & 1.25 & 2.27 & 2.75 \\
\hline 42 & 6.26 & 0.12 & 13.78 & 1.13 & 2.47 & 3.78 \\
\hline 63 & 6.50 & 0.12 & 19.35 & 1.21 & 2.43 & 4.06 \\
\hline 84 & 6.78 & 0.10 & 20.45 & 1.22 & 2.40 & 4.38 \\
\hline $\mathrm{P}$ & 0.0024 & 0.0125 & 0.0458 & 0.0496 & 0.3569 & 0.0129 \\
\hline Mean & 6.03 & 0.14 & 18.64 & 1.26 & 2.36 & 3.66 \\
\hline $\mathrm{CV}$ & 21.80 & 39.62 & 26.43 & 16.74 & 21.37 & 39.46 \\
\hline $\mathrm{RV}^{*}$ & $6.0-7.9$ & $0.1-2.0$ & $17.1-42.8$ & $1.2-1.9$ & $2.4-3.0$ & $3.5-5.7$ \\
\hline
\end{tabular}

CV: Coefficient of Variation; RV: Reference values according to Kaneko et al. (2008). ${ }^{1} \mathrm{Y}=5.432535+$ $0.015717 \mathrm{X} ; \mathrm{R}^{2}=58.99 \% ;{ }^{2} \mathrm{Y}=0.182182-0.001007 \mathrm{X}, \mathrm{R}^{2}=88.26 \% ;{ }^{3} \mathrm{Y}=21.621714-0.273209 \mathrm{X}+$ $0.003230 \mathrm{X}^{2}, \mathrm{R}^{2}=69.13 \% ;{ }^{4} \mathrm{Y}=1.441866-0.010774 \mathrm{X}+0.000101 \mathrm{X}^{2}, \mathrm{R}^{2}=93.01 \% ;{ }^{5} \mathrm{Y}=3.143048+$ $0.01375 \mathrm{X}, \mathrm{R}^{2}=55.12 \%$.

The results showed no effect of the different $\mathrm{R}: \mathrm{C}$ ratios on the protein metabolites evaluated. For the evaluation periods, total proteins, uric acid and globulins followed linear equations, indicating an increase in total proteins and globulins and a decrease in uric acid. Urea and creatinine showed quadratic responses for the period.

Total proteins and globulin remained within the range recommended by Kaneko et al. (2008), indicating that there was no protein deficiency in the diet and adequate protein intake. Throughout the experiment, the serum concentrations of total proteins increased linearly, possibly because of: 1) the protein demand for muscle deposition, which increases in the growth stage (REGADAS FILHO et al., 2011), 2) the fact that they are 
confined receiving diets with high digestibility (Table 3), and 3) the increase in DMI (Graphic 1), which increases protein intake, augmenting the concentration of total blood proteins. Creatinine was not influenced by the treatments and remained within the values considered normal for the species (1.2 to $1.9 \mathrm{~g} / \mathrm{dL}$ ), causing no renal alteration. Uric acid also remained within the reference range $(0.1$ to $2.0 \mathrm{~g} / \mathrm{dL})$. This metabolite is directly related to the synthesis of microbial protein by ruminal microorganisms. Thus, what possibly caused a linear reduction in uric acid levels was the reduction in dry matter consumption at the end of confinement (Graphic 1), since the intake is directly related to the microbial synthesis in the rumen.

Urea demonstrates the protein status in the short term, while albumin demonstrates in the long term. Although the concentration of albumin is below the reference values (approximately 1.6\%) proposed by Kaneko et al. (2008), this should not be used as the sole indicator of protein status. In contrast, the urea values showed that there was a beneficial relationship between protein and energy, showing synchrony between protein degradation and the availability of energy in the rumen, since the blood concentrations of urea remained in the optimal range recommended for the species $(17,17$ to $42.88 \mathrm{mg} / \mathrm{dL}$ ). In addition, the quadratic increase in the concentration of urea in the blood may be related to the extrusion process, which denatures the protein, thus increasing its fermentability in the rumen. Thus, with the analysis of the set of these metabolites, it appears that the dietary protein was correctly balanced, thereby favoring both the demand for ruminal microorganisms and meeting their protein needs.

\section{Conclusion}

The extruded ration changes the pattern of rumen fermentability, significantly increasing gas production to the extent of increased inclusion of 
concentrate in the diet and directly affecting the dry matter intake. Extruded ration produces changes in energy, protein and liver metabolism while not causing liver or kidney damage.

\section{Ração extrusada em diferentes relações de volumoso e concentrado: cinética de fermentação in vitro e avaliação do perfil metabólico de borregas}

Resumo: Objetivou-se avaliar (i) o perfil metabólico de borregas alimentadas com volumoso e concentrado extrusados em diferentes proporções de volumoso:concentrado (V:C) e (ii) a cinética de fermentação ruminal in vitro dessas rações. Foram utilizadas 20 fêmeas mestiças $1 / 2$ Dorper x $1 / 2$ Santa Inês recém-desmamadas com $120 \pm 8$ dias de idade. Os tratamentos foram quatro relações de volumoso extrusado $\left(\right.$ Foragge $^{\circledR}$ ) e concentrado extrusado (Beef Total ${ }^{\circledR}$ ): $30 \% \mathrm{~V}: 70 \% \mathrm{C}, \quad 40 \% \mathrm{~V}: 60 \% \mathrm{C}$, $50 \% \mathrm{~V}: 50 \% \mathrm{C}$ e $60 \% \mathrm{~V}: 40 \% \mathrm{C}$, distribuídos inteiramente ao acaso com cinco repetições. Os metabólitos energéticos analisados foram: VLDL, triglicerídeos e colesterol. Os metabólitos hepáticos foram: fosfatase alcalina, gama glutamiltransferase (GGT) e aspartatoaminotransferase (AST). Os metabólitos proteicos avaliados foram: proteínas totais, ácido úrico, ureia, creatinina, albumina e globulina. A quantificação da produção in vitro de gás foi feita com as rações extrusadas inoculadas em líquido ruminal de bovinos, avaliando as seguintes proporções volumoso:concentrado: $\quad 30 \% \mathrm{~V}: 70 \% \mathrm{C}, \quad 40 \% \mathrm{~V}: 60 \% \mathrm{C}, \quad 50 \% \mathrm{~V}: 50 \% \mathrm{C}$, $60 \% \mathrm{~V}: 40 \% \mathrm{C}$ e $70 \% \mathrm{~V}: 30 \% \mathrm{C}$. Os valores de cinética de fermentação foram comparados por meio do teste de paralelismo e identidade de curvas ao nível de 5\% de probabilidade de erro. Para comparação das médias dos metabólitos, foi adotado estudo de regressão a $5 \%$ de probabilidade de erro. Os dados médios de consumo de matéria seca são apresentados de forma descritiva. A ração extrusada provocou aumento nas enzimas hepáticas (GGT e AST), sem provocar lesões hepáticas e manteve estáveis os metabólitos energéticos. Similarmente, os níveis séricos proteicos permaneceram nos níveis normais recomendados para a espécie. O padrão de fermentação in vitro mostrou alta produção de gases associadas à alta digestibilidade da ração. A ração extrusada fornece aporte energético e proteico para atender às demandas nutricionais dos animais sem comprometer a sua saúde.

Palavras-chave: Energia, Ovis aries, Proteína, Ruminante. 


\section{References}

DUKES, H. H.; SWENSON, M. J. Fisiologia de los animales domesticos. 1 ed. Mexico: Aguillar. 1977. 1054p.

ELLIS, J. L.; DIJKSTRA, J.; KEBREAB, E.; BANNINK, A.; ODONGO, N. E.; McBRIDE, B. W.; FRANCE, J. Aspects of rumen microbiology central to mechanistic modelling of methane production in cattle. Journal of Agricultural Science, v. 146, p. 213-233, 2008. https://doi.org/10.1017/S0021859608007752

FRANCE, J.; DHANOA, M. S.; THEODOROU, M. K.; LISTER, S. J.; DAVIES, D. R.; ISAC, D. A model to interpret gas accumulation profiles associated with in vitro degradation of ruminant feeds. Journal of Theoretical Biology, v. 163, n. 1, p. 99111, 1993. https://doi.org/10.1006/jtbi.1993.1109

FRIEDEWALD, W. T,; LEVV, R. I.; FREDRICKSON, D. S. Estimation of the concentration of low-density lipoprotein in plasma, without use of the preparative $\begin{array}{llllll}\text { ultracentrifuge. Clinical Chemistry, v. } 18, \quad \text { p. } 499-502, & 1972 .\end{array}$ https://doi.org/10.1093/clinchem/18.6.499

GIALLONGO, F.; OH, J.; FREDERICK, T.; ISENBERG, B.; KNIFFEN, D. M.; FABIN, R. A.; HRISTOV, A. N. Extruded soybean meal increased feed intake and milk production in dairy cows. Journal of Dairy Science, v. 98, n. 9, p. 6471-6485, 2015. https://doi.org/10.3168/jds.2015-9786

KANEKO, J. J.; HARVEY, J. W.; BRUSS, M. L. Clinical biochemistry of domestic animals. 6 ed. New York: Academic Press; 2008. 928p.

KOZLOSKI, G. V.; TREVISAN, L. M.; BONNECARRÈRE, L. M.; HÄRTER, C. J.; FIORENTINI, G.; GALVANI, D. B.; PIRES, C. C. Níveis de fibra em detergente neutro na dieta de cordeiros: consumo, digestibilidade e fermentação ruminal. Arquivo Brasileiro de Medicina Veterinária e Zootecnia, v. 58, n. 5, p. 893-900, 2006. https://doi.org/10.1590/S0102-09352006000500027 
LIMA JÚNIOR, D. M.; BRAGA, A. P.; RANGEL, A. H. N.; BRAGA, Z. C. A. C.; BARRETO, H. F. M.; MACIEL, M. V. Farelo de algodão (Gossipum spp.) extrusado na dieta de ruminantes: consumo e digestibilidade. Acta Veterinaria Brasilica, v. 5, n. 1, p. $68-75,2011$.

MEIRA JÚNIOR, E. B. S.; RIZZO, H.; BENESI, F.J.; GREGORY, L. Influência dos fatores sexuais e etários sobre a proteína total, fração albumina e atividade sérica de aspartato-aminotransferase e gama-glutamiltransferase de ovinos da raça Santa Inês. Brazilian Journal of Veterinary Research and Animal Science, v. 46, n. 6, p. 448-454, 2009. https://doi.org/10.11606/S1413-95962009000600003

MENKE, K. H.; RAAB, L.; SALEWSKI, A.; STEINGASS, H.; FRITZ, D.; SCHNEIDER, $\mathrm{W}$. The estimation of the digestibility and metabolizable energy content of ruminant feedingstuffs from the gas production when they are incubated with rumen liquor in vitro. Journal of Agricultural Science, v. 93, n. 1, p. 217-222, 1979. https://doi.org/10.1017/S0021859600086305

MOREIRA, P. C.; REIS, R. B.; REZENDE, P. L. P.; MENDONÇA, A. C.; WASCHECK, R. C.; MARTINS, A. F. Produção de ácidos graxos voláteis, avaliada pela técnica semiautomática in vitro, na dieta de ruminantes com diferentes fontes de carboidratos na fração volumosa. Ciência Animal Brasileira, v. 10, n. 2, p. 413-424, 2009.

NUNES, A. S.; OLIVEIRA, R. L.; AYRES, M. C. C.; BAGALDO, A. R.; GARCEZ NETO, A. F.; BARBOSA, L. P. Condição hepática de cordeiros mantidos com dietas contendo torta de dendê proveniente da produção de biodiesel. Revista Brasileira de Zootecnia, v. 39, n. 8, p. 1825-1831, 2010. https://doi.org/10.1590/S1516$\underline{35982010000800027}$

PEIXOTO, L. A. O.; OSÓRIO, M. T. M. Perfil metabólico proteico e energético na avaliação do desempenho reprodutivo em ruminantes. Revista Brasileira de Agrociência, v. 13, n. 3, p. 299-304, 2007. 
REGADAS FILHO, J. G. L.; PEREIRA, E. S.; VILLARROEL, A. B. S.; PIMENTEL, P. G.; FOnTENELE, R. M.; COSTA, M. R. G. F.; MAIA, I. S. G.; SOMBRA, W. A. Efficiency of metabolizable energy utilization for maintenance and gain and evaluation of Small Ruminant Nutrition System model in Santa Ines sheep. Revista Brasileira de Zootecnia, v. 40, n. 11, p. 2558-2564, 2011. https://doi.org/10.1590/S1516$\underline{35982011001100038}$

REGAZZI, A. J.; SILVA, C. H. O. Teste para verificar a igualdade de parâmetros e a identidade de modelos de regressão não-linear. Revista de Matemática e Estatística, v. 22, n. 2, p. 33-45, 2004.

SILVA, S. N. Crescimento e desenvolvimento de ovinos da raça Santa Inês. 2017. 65f. Dissertação (Mestrado em Zootecnia) - Universidade Estadual do Sudoeste da Bahia, Itapetinga, 2017.

SOUSA, L. F.; MACEDO JÚNIOR, G. L.; SANTOS, R. P.; SILVA A. G. M.; BORGES, I. Composição bromatológica e cinética da fermentação ruminal de rações contendo resíduos de babaçu. Revista Ciência Agronômica, v. 45, n. 1, p. 177-185, 2014. https://doi.org/10.1590/S1806-66902014000100021

VARANIS, L. F. M. Prospecção de metabólitos sanguíneos referenciais para ovinos em distintas categorias. 2018, 88f. Dissertação (Mestrado em Ciências Veterinárias) - Universidade Federal de Uberlândia, Uberlândia, 2018. 